\title{
Public health nutrition in Afghanistan-policies, strategies and capacity-building: current scenario and initiatives
}

Jyoti Sharma, ${ }^{1}$ Homayoun Ludin, ${ }^{2}$ Monika Chauhan ${ }^{1}$ and Sanjay Zodpey ${ }^{1}$

${ }^{1}$ Indian Institute of Public Health Delhi, Public Health Foundation of India, Delhi, India (Correspondence to: Jyoti Sharma: jyoti@iiphd.org). ${ }^{2}$ Ministry of Public Health, Kabul, Afghanistan.

\begin{abstract}
Background: Afghanistan is grappling with high burden of malnutrition in women and children and a rising burden of noncommunicable diseases.

Aims: A narrative review was conducted with the aim of mapping current nutrition policies and capacity development initiatives to assess policy and the institutional environment and identify gaps and opportunities.

Methods: A comprehensive, broad based search was conducted, including databases and websites and policy and programme documents.

Results: The policy focuses on multisectoral efforts to address nutrition challenges; however; implementation of nutrition-specific and nutrition-sensitive interventions is not delivered uniformly at the community level due to continued conflic situations and geographic inaccessibility, lack of availability of trained human resources and weak institutions. There is limited evidence on the effectiveness of nutrition programmes in Afghanistan. Limited policy provisions are available to address nutrition issues due to the rising burden of noncommunicable diseases, urbanization and changing dietary patterns. The shortage of skilled nutritional professionals is a critical issue. Lack of institutional capacity, educational standards and accreditation mechanism poses major challenges. Ongoing training programmes are fragmented and fail to meet the requirements of a professional nutrition workforce.
\end{abstract}

Conclusion: The findings highlight that well-structured policies and strategies focusing on maternal and child nutrition provide an enabling policy environment to scale up nutrition interventions. Evidence on the implementation of programmes is needed to aid policy recommendations. The lack of an institutional mechanism for professional nutrition education highlights the great need for action in Afghanistan for public health nutrition and education.

Keywords: Afghanistan, nutrition policy, nutrition strategy, capacity-building, public health nutrition

Citation: Sharma J; Ludin H; Chauhan M; Zodpey S. Public health nutrition in Afghanistan-policies, strategies and capacity-building: current scenario and initiatives. East Mediterr Health J. 2021;27 (7):728-737. https://doi.org/10.26719/emhj.21.043

Received: 02/06/20; accepted: 20/12/20

Copyright $($ C World Health Organization (WHO) 2021. Open Access. Some rights reserved. This work is available under the CC BY-NC-SA 3.0 IGO license (https://creativecommons.org/licenses/by-nc-sa/3.o/igo).

\section{Introduction}

The nutritional status of a population has a well-established profound effect on health and economic development (1-4). Nearly half of all deaths in children under 5 years are attributable to undernutrition, which translates into the loss of about 3 million young lives a year (5). Many low- and middle-income countries continue to face high levels of malnutrition resulting from poverty, food insecurity, food wastage and social and political situations. With recognition of its consequences for a wide range of human, social and economic outcomes, the role of nutrition in achieving the Sustainable Development Goals is acknowledged globally and has gained unprecedented attention in the global policy arena (6-10). The current impetus has brought nutrition to the centre stage in the development agenda in low- and middle-income countries, with intensive efforts to invest and address the problem of malnutrition (11).

The under-nutrition spectrum of Afghanistan, with widespread micronutrient deficiencies, highlights the high prevalence of nutritional disorders, morbidities and mortality, particularly in mothers and children (6). It is important to understand the context that the Government of Afghanistan was facing in 2002. After decades of conflict and instability, the health system was completely dysfunctional, the physical infrastructure was ruined and educational institutes were destroyed. Access to health services was highly restricted for women and girls and their participation in education and the work force was banned. Maternal and child health indicators were very poor (12). After 2002, with continued volatile social and political situations, considerable efforts have been made to rebuild the health system (13). With extensive support from humanitarian organizations, health system reforms focused on rebuilding the health system and increasing the coverage of primary health care services. The basic package of health services (BPHS) and the essential package of hospital services (EPHS) contracted to nongovernmental organizations with a focus on increasing coverage of vaccination and other disease control programmes. After a decade of implementation of these services, a $30 \%$ reduction in mortality among 
children under 5 years was observed (14). In 2018, a total of 3135 health facilities were functional in the country, which ensured health access within 2 hours distance to almost $87 \%$ of the population $(15,16)$. Despite this progress, Afghanistan continues to be one of the most fragile countries in South Asia, ranking 108th of 117 countries on the Global Hunger Index and 42nd of 45 countries by the Hunger and Nutrition Commitment Index on the country government's political commitment to tackling hunger and malnutrition $(17,18)$. Wide geographical and ethnic disparities and high private out-of-pocket expenditure are continuing challenges $(15,19)$.

With the recent thrust to tackle the nutrition problems, the Government of Afghanistan has launched several strategic initiatives to address the burden of malnutrition with the support of the United Nations and other humanitarian organizations. Although efforts have been made to improve the policies and structuring of nutrition programmes, the nutrition agenda of the country must be aligned to deal with upcoming new challenges arising due to climate change and environment, the increasing prevalence of noncommunicable diseases, poverty, population growth, urbanization and changing dietary patterns. Furthermore, translating policies into action at the grass roots level is not possible without an efficient and skilled nutrition workforce. The nutrition programme goals of the country cannot be accomplished without investing in the capacities of people, organizations and institutions. Skills and knowledge of the nutrition workforce to design, plan and monitor nutrition interventions as well as effective programme delivery are important for successful nutrition actions $(20,21)$.

Although a positive impact on nutrition outcomes has been documented, there is limited evidence on the effectiveness of the nutrition programmes and capacity-building initiatives to develop a skilled nutrition workforce (22).

This narrative review attempts to map and describe the nutrition policies and programmes of Afghanistan with the aim of assessing the nutrition policy and institutional environment for responding to the current nutrition conditions faced by the country and its alignment towards addressing future challenges. The review also attempts to explore professional nutrition education initiatives to develop a skilled nutrition workforce in Afghanistan with a view to understanding its status, gaps and opportunities.

\section{Methods}

We conducted a literature search for nutrition-related policies, programmes, training and capacity-building activities published from Afghanistan and in peer reviewed research papers. The literature search was performed using Google, Google Scholar and PubMed.

The policy and programme documents and reports were searched using a combination of search terms and phrases, including: health and nutrition status, health systems in Afghanistan, nutrition in Afghanistan, nutrition policy of Afghanistan, nutrition strategy of Afghanistan, health policy of Afghanistan, nutrition status of Afghanistan, nutrition institutes in Afghanistan, nutrition training in Afghanistan, nutrition diploma, nutrition courses in Afghanistan, community nutrition programme in Afghanistan.

Examples of search terms for PubMed include: (nutrition) AND (child nutrition) OR (maternal nutrition) OR(maternalundernutrition)OR(stunting[MeSHTerms]) OR (wasting[MeSH Terms]) OR (undernutrition[MeSH Terms]) OR (anemia[MeSH Terms]) OR (infant and child feeding) OR (breastfeeding[MeSH Terms]) OR (complimentary feeding[MeSH Terms]) AND (Afghanistan[MeSH Terms]).

The search was restricted to the last 10 years, conducted on humans and published in the English language. The reference list of selected articles was hand searched for relevant sources. The electronic search was also supplemented by a snowball approach to get information in the form of reports, documents and other literature published by various agencies working in Afghanistan.

Information pertaining to health and nutrition outcomes was derived from various national surveys and policy documents. We contacted the Public Nutrition Directorate at the Ministry of Public Health to obtain documents and reports related to programmes, ongoing training and their status. Information on recent capacitybuilding initiatives was also sought.

All information and data obtained are available in the public domain and are used with the permission of the Public Nutrition Directorate, Ministry of Public Health, Afghanistan.

\section{Results}

\section{Nutrition landscape of Afghanistan}

The Human Development Index for Afghanistan is one of the lowest in the world, with over one third of population living below the national poverty line and one third facing food insecurity (23). Child and maternal undernutrition is still a huge challenge, again among the worst in the world (Table 1). The undernutrition spectrum with widespread micronutrient deficiencies is characterized by wide regional inequalities and difficult geographical and sociopolitical circumstances (24). Nevertheless, increased investment in the social sector during the last decade resulted in improvement in maternal and child health and nutrition outcomes; for example, the 2013 data indicate that the prevalence of stunting (or chronic malnutrition) has decreased by about 20 percentage points since 2004 , ranging from about $24 \%$ to $>70 \%$ across the country. The undernourishment of women of reproductive age dropped to about $9 \%$ in 2013 . A significant improvement in iodine status was observed, with the median urinary iodine concentration among school age children dropping from $>170 \mu \mathrm{g} / \mathrm{L}$ in 2013 to $49 \mu \mathrm{g} / \mathrm{L}$ in 2004. The findings of the National Nutrition Survey 
Table 1 Health and nutrition indicators in Afghanistan

\begin{tabular}{|c|c|c|c|}
\hline Mortality indicator & $\begin{array}{c}\text { Afghanistan Mortality } \\
\text { Survey } 2010\end{array}$ & $\begin{array}{l}\text { Demographic and } \\
\text { Health Survey } 2015\end{array}$ & $\begin{array}{c}\text { Afghanistan Service } \\
\text { Provision Survey } 2018\end{array}$ \\
\hline Infant mortality rate per 1000 live births & 77 & 45 & 41 \\
\hline Under-5 mortality rate per 1000 live births & 97 & 55 & 50 \\
\hline Maternal mortality ratio per 100000 births $^{a}$ & 954 & 701 & 638 \\
\hline Malnutrition prevalence ${ }^{b}$ & $2004(\%)$ & $2013(\%)$ & $2018(\%)^{c}$ \\
\hline Stunting in children under 5 years & 60.5 & 40.9 & 37.0 \\
\hline Wasting in children under 5 years & 8.7 & 9.5 & 5.0 \\
\hline \multicolumn{4}{|l|}{ Undernutrition $\mathrm{BMI}<18.5$} \\
\hline In adolescent girls aged 10-19 years & & 8.0 & - \\
\hline In women of reproductive age group & 20.9 & 9.2 & - \\
\hline \multicolumn{4}{|l|}{ Iodine deficiency disorder } \\
\hline In children under 5 years & 71.9 & 29.5 & - \\
\hline In women of reproductive age group & 74.7 & 40.8 & - \\
\hline \multicolumn{4}{|l|}{ Anaemia } \\
\hline In children under 5 years & 37.9 & 44.9 & - \\
\hline In women of reproductive age group & 24.7 & 40.4 & - \\
\hline \multicolumn{4}{|l|}{ Vitamin A deficiency } \\
\hline In children under 5 years & & 11.3 & - \\
\hline In women of reproductive age group & & 50.4 & - \\
\hline \multicolumn{4}{|l|}{ Zinc deficiency } \\
\hline In children under age 5 & & 15.1 & - \\
\hline In women of reproductive age group & & 23.4 & - \\
\hline \multicolumn{4}{|l|}{ Vitamin D deficiency } \\
\hline In children under 5 years & & 81.0 & - \\
\hline In women of reproductive age group & & 95.5 & - \\
\hline
\end{tabular}

aInternationally comparable MMR estimates by the Maternal Mortality Estimation Inter-Agency Group (MMEIG) WHO, UNICEF, UNFPA, World Bank Group and the United Nations

Population Division, https://www.who.int/gho/maternal_health/countries/afg.pdf.

${ }^{b}$ National Nutrition Survey Afghanistan (2004 \& 2013 (6).

${ }^{c}$ Afghanistan Service Provision Assessment Survey 2018-19.

2013 highlighted the rising burden of overweight and obesity in Afghanistan, with $5.4 \%$ of children under 5 years, $11.6 \%$ of adolescent girls and about one fifth (20.7\%) of women of reproductive age (15-49 years) overweight. Widespread micronutrient deficiencies continued to remain a public health challenge, with more than $95 \%$ women of reproductive age deficient in vitamin $\mathrm{D}$ and $40 \%$ affected by anaemia $(24,25)$. Equity is a central issue associated with nutrition: disparities in nutritional status in Afghanistan exist across geographic locations and socioeconomic groups. Although undernutrition status is influenced poverty, other determinants such as hygiene and sanitation, suboptimal feeding practices, gender norms and availability of health services also contribute significantly $(26,27)$.

\section{Policy and programme initiatives to address nutrition issues in Afghanistan}

Since 2001, through the efforts of local government and humanitarian organizations, the status of maternal and child nutrition indicators has been improving slowly. Subsequently, the Public Nutrition Department within the structure of the Ministry of Public Health was established in 2002 to look after the implementation of nutrition programmes in the country. With the support of United Nations agencies and the donor community, in 2003 the Ministry of Public Health developed the first National Public Nutrition Policy and Strategy and later revised it (2009-2013) $(23,28,29)$. Initial nutrition policies focused on health interventions within the facilities through safe motherhood initiatives to improve antenatal care, counselling, providing micronutrient supplementation and offering nutrition education at facility and community levels. The child nutrition initiatives focused on care of severe acute malnourished children at the facilities and household intake of fortified foods. Subsequently, several nutrition-related policies and strategies were developed, including the strategy on prevention and control of vitamin and mineral deficiencies (2009) and the infant and young child feeding strategy (2009). The Nutrition Action Framework and the Afghanistan Food Security and Nutrition Agenda (known as AFSANA, and changed to AFSeN in April 2017) were developed, and multisector action was prioritized to improve nutrition (30). The National Health Strategy 2015-2020 of the Ministry of Public Health came into force to focuse 
on governance, institutional development, public health, health services and human resources (28).

The government has shown the highest political commitment (2015) as a part of a renewed call to action for maternal and child survival through the Kabul Declaration. The Government made a new commitment to reduce stunting in children under 5 years of age to $35 \%$ by 2020 and $10 \%$ by 2030 . Many public health strategies and policies have been developed by the government to mitigate the consequence of undernutrition in the Afghan population in the near future. $(28,31)$. The Public Nutrition Strategy 2015-2020 is an effort aligned with global momentum for improving maternal and child nutrition; the nutrition strategy of the country focuses on the first thousand days from conception to 2 years of age through a combination of nutrition-sensitive and nutrition-specific approaches. The priority themes of the nutrition policy include: nutrition promotion, maternal nutrition, infant and young child feeding, micronutrients, adequate care during severe acute malnutrition, food safety and quality control, effective nutritional surveillance and monitoring, response to nutritional emergencies and capacity development for public nutrition and multisectoral coordination. (31). To achieve these priorities, a number of programmes and activities have been initiated (Table 2).

These programmes strive to achieve increased access to nutrition services and products, improved nutrition behaviour and practices, improved quality of nutrition services and products and a strengthened social, regulatory and political environment for nutrition. In addition, national standard operation procedures and guidelines were formulated to push the agenda forward through the health systems. These standard operation procedures and guidelines include infant and young child feeding, management of inpatient severe acute malnutrition, integrated management of acute malnutrition, nutrition in emergency, weekly iron folic acid supplementation, micronutrient supplementation and baby friendly hospital initiatives, etc. An elaborate multisectoral plan for the development and implementation of nutrition programmes across 5 government ministries, Public Health, Agriculture, Commerce, Education, and Rural Development, with clearly defined roles and responsibilities is also outlined in the strategy. Additionally, the formulation of several regulations (to protect breastfeeding and universal salt iodization) and the enactment of several nutritionspecific legislations (e.g. fortified food standards, supplementary and complementary food standards) illustrate the government's commitment to improving the nutrition situation of the Afghan people (31,32). A highly relevant policy framework generally helped in creating a positive environment for nutrition actions in Afghanistan. Basic building blocks for the scale-up of nutrition interventions are the BPHS and the EPHS.

Though, the nutrition policy framework aims to address nutrition challenges of populations with nutrition-specific and nutrition-sensitive interventions, most BPHS and EPHS facilities are not able to provide a complete package of nutrition services. Implementation is often constrained by a shortage of human resources, low capacities of the workforce, lack of regular funding, a volatile security situation and a lack of demand for services $(33,34)$.

Programme-based reporting and monitoring does take place, but the lack of a consistent monitoring and evaluation mechanism, the absence of standardized indicator definitions and few longitudinal nutrition surveys hamper the accumulation of sufficient evidence to show meaningful changes $(22,29)$.

Additionally, the policy framework lacks the vision to address forthcoming nutrition challenges such as the rising burden of noncommunicable diseases, urbanization, climate change and changing dietary habits.

\section{Public health nutrition workforce and capacity-building initiatives in Afghanistan}

There is a growing consensus that a robust and knowledgeable workforce is essential for public health nutrition policy implementation. (35). The approaches to building the nutrition workforce are proposed in the nutrition policy, but the operational mechanism remains unclear. The main initiatives regarding capacity-development for public nutrition has been the establishment of the Public Nutrition Department within the Ministry of Public Health and the training of provincial nutrition officers. Provincial nutrition officers are responsible for coordinating and monitoring nutrition-related activities and training BPHS staff in nutrition services. The nutrition implementing partners report their activities according to the standard formats developed by the Public Nutrition Directorate. The progress of implementation activities is supervised by the nutrition officers of the implementing partner and the provincial nutrition officers at the provincial level $(22,32)$

Defining the human resource needs for 398 districts to deliver quality nutrition services across a large and diverse population scattered in the mountains and valleys is truly challenging. The shortage of trained human resource remains a major issue (14), most often as a result of the continuous and widespread insecurity, local customs, harsh climate, remote scattered location of the population, illiteracy and political pressures. Moreover, the continuing conflict has resulted in the displacement and migration of trained professionals from the country. Health professionals who are currently working in the health system have missed opportunities of continuing education and information on international developments in health care delivery, leadership and management. Recent research highlighted that about 70\% of staff in Afghanistan do not meet minimum knowledge and skill standards $(36,37)$. This calls for developing a welltrained public health nutrition cadre, schooled in the basic concepts and principles of public health nutrition as well as having been appropriately trained in the 
Table 2 Nutrition programmes of Afghanistan

\begin{tabular}{|c|c|c|c|}
\hline Programme & Partner agencies & Focus area & Target/indicators \\
\hline Public nutrition in BPHS & $\begin{array}{l}\text { Public Nutrition } \\
\text { Directorate, Ministry } \\
\text { of Public Health; World } \\
\text { Bank; USAID; European } \\
\text { Union }\end{array}$ & $\begin{array}{l}\text { BPHS/EPHS, system } \\
\text { strengthening, nutrition } \\
\text { communication/ advocacy }\end{array}$ & Delivery of health nutrition services \\
\hline $\begin{array}{l}\text { Infant and young child } \\
\text { feeding }\end{array}$ & $\begin{array}{l}\text { Public Nutrition } \\
\text { Directorate Ministry of } \\
\text { Public Health; UNICEF; } \\
\text { WHO }\end{array}$ & $\begin{array}{l}\text { Breastfeeding \& } \\
\text { complementary feeding }\end{array}$ & $\begin{array}{l}\text { Promoting and supporting early and exclusive breastfeeding } \\
\text { until } 6 \text { months, among working mothers } \\
\text { Early initiation of breastfeeding: }>70 \% \text {, exclusive } \\
\text { breastfeeding: }>60 \% \\
\text { Promoting optimal complementary feeding with multi- } \\
\text { micronutrient powders, or commercially produced fortified } \\
\text { complementary foods }>40 \% \text { coverage }\end{array}$ \\
\hline $\begin{array}{l}\text { Integrated management } \\
\text { of acute malnutrition }\end{array}$ & $\begin{array}{l}\text { Public Nutrition } \\
\text { Directorate Ministry of } \\
\text { Public Health; UNICEF; } \\
\text { WHO }\end{array}$ & $\begin{array}{l}\text { Management of severe } \\
\text { acute malnutrition } \\
\text { and moderate acute } \\
\text { malnutrition }\end{array}$ & $\begin{array}{l}\text { Integrated management of children }<5 \text { years old (especially } \\
\text { those }<24 \text { months old) with severe acute malnutrition through } \\
\text { in-patient and out-patient treatment }>70 \% \text { coverage } \\
\text { Early identification and supplementary feeding of }<5 \text { year old } \\
\text { children (with a special focus on }<2 \text { year olds) with moderate } \\
\text { acute malnutrition }>70 \% \text { coverage }\end{array}$ \\
\hline $\begin{array}{l}\text { Micronutrient } \\
\text { supplementation }\end{array}$ & $\begin{array}{l}\text { Public Nutrition } \\
\text { Directorate Ministry } \\
\text { of Public Health, } \\
\text { micronutrient initiative }\end{array}$ & $\begin{array}{l}\text { Vitamins, vitamin D, iron, } \\
\text { folic acid, calcium and zinc }\end{array}$ & $\begin{array}{l}\text { Multi-micronutrient supplementation for non-pregnant } \\
\text { adolescent girls and adult women }>60 \% \text { coverage } \\
\text { Semi-annual vitamin A supplementation for children 6-59 } \\
\text { months }>95 \% \text { coverage }\end{array}$ \\
\hline Food Fortification & $\begin{array}{l}\text { Public Nutrition } \\
\text { Directorate Ministry of } \\
\text { Public Health, World } \\
\text { Food Programme, } \\
\text { USAID }\end{array}$ & Iodine & $\begin{array}{l}\text { Strengthening the existing mandatory salt iodization } \\
\text { programme }>90 \% \text { coverage } \\
\text { Promulgating and enforcing mandatory law on fortification of } \\
\text { industrially produced domestic and imported vegetable oil and } \\
\text { ghee with vitamins A and D }>80 \% \text { coverage }\end{array}$ \\
\hline $\begin{array}{l}\text { Food based dietary } \\
\text { guidelines }\end{array}$ & $\begin{array}{l}\text { Public Nutrition } \\
\text { Directorate Ministry } \\
\text { of Public Health, } \\
\text { Food and Agriculture } \\
\text { Organization }\end{array}$ & $\begin{array}{l}\text { Dietary adequacy, nutrition } \\
\text { education and behaviour } \\
\text { change }\end{array}$ & $\begin{array}{l}\text { Promoting use of national food based dietary guideline among } \\
\text { families as well as other social institutions }>50 \% \text { knowledge }\end{array}$ \\
\hline Maternal nutrition & $\begin{array}{l}\text { Public Nutrition } \\
\text { Directorate Ministry of } \\
\text { Public Health, World } \\
\text { Food Programme }\end{array}$ & $\begin{array}{l}\text { Nutrition during } \\
\text { pregnancy }\end{array}$ & $\begin{array}{l}\text { Supplementing food for pregnant and lactating women with } \\
\text { undernutrition in food insecure area }>70 \% \text { coverage } \\
\text { Promoting balanced and micronutrients rich diet for pregnant } \\
\text { and lactating women }>40 \% \text { coverage }\end{array}$ \\
\hline Nutrition surveillance & $\begin{array}{l}\text { Public Nutrition } \\
\text { Directorate Ministry } \\
\text { of Public Health, } \\
\text { Department of Foreign } \\
\text { Affairs, Trade and } \\
\text { Development Canada }\end{array}$ & $\begin{array}{l}\text { Nutrition monitoring and } \\
\text { surveillance }\end{array}$ & $\begin{array}{l}\text { Improving the quality of the nutrition programme-related data } \\
\text { through the health management information system } \\
\text { Strengthening coordination with relevant units of the } \\
\text { Ministry of Public Health toward routine monitoring and } \\
\text { supportive supervision of nutrition services in by BPHS and } \\
\text { EPHS facilities (including appropriate use of the basic score } \\
\text { card and nutrition programme monitoring checklists) }\end{array}$ \\
\hline $\begin{array}{l}\text { Nutrition } \\
\text { communication strategy }\end{array}$ & $\begin{array}{l}\text { Public Nutrition } \\
\text { Directorate Ministry of } \\
\text { Public Health }\end{array}$ & $\begin{array}{l}\text { Communication and } \\
\text { behaviour change }\end{array}$ & $\begin{array}{l}\text { Promoting proper nutrition and care during the first } 1000 \text { days } \\
\text { of life, through mass communication and campaigns } \\
\text { Strengthening the ability of maternal and child health care } \\
\text { providers to deliver appropriate preventive and therapeutic } \\
\text { food and nutrition messages to their patients }\end{array}$ \\
\hline
\end{tabular}

Sources: National health policy (2015-2020) (19); National nutrition strategy (2015-2020) (20); Standard operating procedure and guidelines for BHPS (22).

BPHS = basic package of health services.

$E P H S=$ essential package of hospital services

planning and management of large scale public health programmes (35,38).

Public health education is part of the medical curriculum offered by medical universities (39). No dedicated nutrition degree/diploma programme exists in the country. Hence, professionals hired to work in health facilities and in nongovernmental organizations to implement nutrition programmes lack professional nutrition qualifications and often do not meet minimum knowledge and skills (Table 3).
To carry out implementation activities, many nutrition training courses and workshops have been conducted to improve the skills and knowledge of the health care workers and other staff at central, provincial, district and community levels (Table 3). These short-term courses and workshops are limited and often do not cover the wider aspects relating to nutrition programmes and the wider public health aspects, including the planning, implementation and evaluation of public nutrition programmes. Moreover, training of dieticians to provide clinical nutrition services has still not been initiated. 


\begin{tabular}{|c|c|c|c|c|}
\hline Health worker & $\begin{array}{c}\text { Requisite } \\
\text { qualification for } \\
\text { entry into job }\end{array}$ & $\begin{array}{l}\text { Health facility } \\
\text { level }\end{array}$ & Type of training & $\begin{array}{l}\text { Trainings conducted/ } \\
\text { planned }\end{array}$ \\
\hline Health volunteer & $\begin{array}{l}\text { Age } 25-50 \text { years from } \\
\text { same community, } \\
\text { preferred to be literate, } \\
\text { be active and an } \\
\text { influential person in the } \\
\text { community }\end{array}$ & Community level & $\begin{array}{l}\text { Community-based nutrition } \\
\text { package }\end{array}$ & To be conducted in 10 provinces \\
\hline \multirow[t]{3}{*}{$\begin{array}{l}\text { Nursing \& paramedical } \\
\text { staff }\end{array}$} & \multirow{3}{*}{$\begin{array}{l}\text { Registered certificate } \\
\text { of graduation from } \\
\text { nursing or midwifery } \\
\text { institutes }\end{array}$} & \multirow[t]{3}{*}{ Facility level } & $\begin{array}{l}\text { Nutrition standard operation } \\
\text { procedures guidelines }\end{array}$ & $\begin{array}{l}\text { Conducted in most of the } \\
\text { provinces }\end{array}$ \\
\hline & & & $\begin{array}{c}\text { Infant and young child feeding } \\
\text { training }\end{array}$ & Conducted in some provinces \\
\hline & & & $\begin{array}{l}\text { Inpatient department - severe } \\
\text { acute malnutrition management }\end{array}$ & $\begin{array}{l}\text { Conducted in most of the } \\
\text { provinces }\end{array}$ \\
\hline \multirow[t]{2}{*}{$\begin{array}{l}\text { Community health } \\
\text { supervisor }\end{array}$} & \multirow{2}{*}{$\begin{array}{l}\text { At least to be high } \\
\text { school graduate; having } \\
\text { nursing and midwifery } \\
\text { certificate is preferable }\end{array}$} & \multirow[t]{2}{*}{ Facility level } & $\begin{array}{l}\text { Nutrition standard operating } \\
\text { procedures guidelines }\end{array}$ & $\begin{array}{l}\text { Conducted in most of the } \\
\text { provinces }\end{array}$ \\
\hline & & & $\begin{array}{l}\text { Community-based nutrition } \\
\text { package }\end{array}$ & To be conducted in 10 provinces \\
\hline \multirow[t]{4}{*}{$\begin{array}{l}\text { Doctor of Medicine } \\
\text { (MD) }\end{array}$} & \multirow{4}{*}{$\begin{array}{l}\text { Having an MD degree } \\
\text { issued by the Ministry } \\
\text { of Public Health is a } \\
\text { must }\end{array}$} & \multirow[t]{4}{*}{ Facility level } & $\begin{array}{l}\text { Nutrition standard operation } \\
\text { procedures guidelines }\end{array}$ & $\begin{array}{l}\text { Conducted in most of the } \\
\text { provinces }\end{array}$ \\
\hline & & & $\begin{array}{l}\text { infant and young child feeding } \\
\text { guidelines }\end{array}$ & $\begin{array}{l}\text { To be conducted if extra budget } \\
\text { is available }\end{array}$ \\
\hline & & & $\begin{array}{l}\text { Inpatient department - severe } \\
\text { acute malnutrition management }\end{array}$ & $\begin{array}{l}\text { Conducted in most of the } \\
\text { provinces }\end{array}$ \\
\hline & & & $\begin{array}{l}\text { Integrated management of acute } \\
\text { malnutrition guideline }\end{array}$ & $\begin{array}{l}\text { To be conducted if extra budget } \\
\text { is available }\end{array}$ \\
\hline \multirow[t]{4}{*}{ Nutrition officers } & \multirow{4}{*}{$\begin{array}{l}\text { MD degree issued by } \\
\text { the Ministry of Public } \\
\text { Health; work experience } \\
\text { in the field of nutrition } \\
\text { for at least } 3 \text { years; } \\
\text { received necessary } \\
\text { nutrition training; } \\
\text { fluent in English and } 2 \\
\text { local languages }\end{array}$} & \multirow{4}{*}{$\begin{array}{l}\text { Basic package of } \\
\text { health services \& } \\
\text { nongovernmental } \\
\text { organizations } \\
\text { provincial level } \\
\text { In the structure of } \\
\text { Provincial Public } \\
\text { Health Directorate at } \\
\text { provincial level }\end{array}$} & $\begin{array}{l}\text { Nutrition standard operation } \\
\text { procedures guidelines }\end{array}$ & $\begin{array}{l}\text { Conducted in most of the } \\
\text { provinces }\end{array}$ \\
\hline & & & $\begin{array}{l}\text { Infant and young child feeding } \\
\text { guidelines }\end{array}$ & $\begin{array}{l}\text { To be conducted if extra budget } \\
\text { is available }\end{array}$ \\
\hline & & & $\begin{array}{l}\text { Inpatient department - severe } \\
\text { acute malnutrition management }\end{array}$ & $\begin{array}{l}\text { Conducted in most of the } \\
\text { provinces }\end{array}$ \\
\hline & & & $\begin{array}{l}\text { Integrated management of acute } \\
\text { malnutrition guideline }\end{array}$ & $\begin{array}{l}\text { To be conducted if extra budget } \\
\text { is available }\end{array}$ \\
\hline
\end{tabular}

Source: Public Nutrition Directorate, Ministry of Public Health, Afghanistan.

The Public Nutrition Directorate of the Ministry of Public Health is steering several initiatives to develop a public health nutrition cadre in the country. Diploma courses have been launched in Afghanistan with the help of development partners. One such initiative, supported by the Aga Khan Foundation, Afghanistan, with technical support from the Public Health Foundation of India, launched a blended diploma course in public health nutrition with a distance learning component combined with periodic mentoring. This diploma course piloted with 25 trained diploma holders. Several other initiatives are in the pipeline with support from the European Union and other partners. With this European Union support, the Public Nutrition Directorate also planned to establish a nutrition department within the structure of Kabul Medical University in Kabul city; this will incorporate nutrition as a separate subject in the curriculum of all health institutes in future.

\section{Discussion}

The current scenario offers both challenges and opportunities for public health nutrition in Afghanistan. It is evident from the review that despite the highest political commitment and an enabling policy environment, progress in the health and nutrition status of women and children remains challenging, with a very high burden of undernutrition among women and children and a rising burden of noncommunicable diseases. Poverty and food insecurity combined with underlying determinants such as poor hygiene and sanitation continue to pose major challenges to the nutritional status of mothers and children. In addition, ongoing conflicts and limited coverage of essential nutrition interventions further exacerbate the situation $(19,24,26,40)$.

The review of the programme and policies highlighted that, with support from international organizations and the stewardship of the Public Nutrition Directorate at the Ministry of Public Health, the country was able 
to progress on developing policies and strategies and provide an enabling policy environment. The highest political commitment with clearly laid-down policies, evidence-based goals and strategies paved the way for scaling up nutrition interventions in the country $(23,31,32)$. The health service delivery system has been rebuilt based on the BPHS delivered by nongovernmental organizations through a contracting mechanism. This categorically helped increase access to and coverage of health services in remote areas $(21,33,41)$. However, further progress would largely be influenced by the capacity of the system (governance, intersectoral and intrasectoral coordination and organizational arrangements, a robust monitoring mechanism, availability of a sufficient and qualified workforce) $(42,43)$.

The availability of trained nutritional professionals is critical for further strengthening of the implementation of nutrition interventions in Afghanistan. A policy on the public health nutrition workforce with a defined structure, the requisite level of qualifications, occupational profiles and training at various levels could help in realizing the nutrition goals suggested in the revised nutrition strategy (2016-2020). Another important and unique challenge in this country with regard to the development of a nutrition workforce is the nonavailability of a university degree and diploma in nutrition. Developing technical collaboration and academic partnerships between governments, national, regional and international academic institutions and humanitarian/development/donor organizations to strengthen training and education institutes can address challenges resulting from the lack of an educational system. Moreover, modern programme delivery methods such as E-learning can be fostered to scale up training courses $(39,44)$. E-learning could provide several options and would be suitable for different levels and settings and may help in building the core competencies of the existing workforce as well as for the new generation $(39,45)$. It has been argued that distance learning alone may not be sufficient and can be challenging for learners due to language and other barriers (46). Moreover, the use of modern technology for education purposes is still not very common in Afghanistan; the lack of recognition further limits the use of distance learning. Therefore, a blended methodology (mix of both traditional and modern learning techniques) involving periodical mentoring by experts along with distance learning can be one of the approaches to addressing these issues.
The new Sustainable Development Goals era, where nutrition is linked to broader systems of health, food and the environment, offers the opportunity to reflect on how the nutrition capacity of professionals can be developed to promote systems thinking and support policies, research, programme planning, financing, and delivery of services $(21,46)$. What should the nutrition training curriculum be? Recently, several requirements for developing the nutrition workforce have been identified, including leadership, ability to work in a multidisciplinary team, communication, advocacy and a set of technical skills $(21,47)$. Standardization of the nutrition curriculum is vital for both in-service and preservice training at different levels and aligning it with policy and programme priorities. Broadening the scope of nutrition training and integrating core nutrition competencies with broader systems of health, food and the environment in the nutrition curriculum can help in improving the implementation of nutrition actions in an intersectoral environment (48). Additionally, updated public health nutrition aspects should be integrated into the curriculum of medical and nursing studies (46). Developing an accreditation mechanism to review and recognize nutrition courses and training programmes as well as the accreditation of training institutes in collaboration with the Ministry of higher Education can help in setting up quality standards for the nutrition curriculum and training.

- To fill the evidence gap on the effectiveness of nutrition programmes in Afghanistan, investment in the implementation of research and a robust monitoring system should be prioritized.

- Efforts should be directed to address equity issues in the coverage of nutrition interventions.

- The policy framework required has to be aligned to deal with imminent nutrition challenges with the rising level of noncommunicable diseases and urbanization and changing dietary patterns.

- Developing a nutrition workforce strategy within the definitive structure of the public health nutrition workforce can be useful to streamline the workforce distribution towards providing preventive as well as therapeutic nutrition services, and make the field of nutrition an attractive career choice.

- A centre for excellence in public health nutrition to lead nutrition education and research initiatives in therapeutic and prevention nutrition can help narrow any gaps in research and academic activities.

\section{Acknowledgement}

We are thankful to Public Nutrition Directorate, Ministry of Public Health in Afghanistan for providing us with information.

Funding: None.

Competing interests: None declared. 


\section{Nutrition de santé publique en Afghanistan - politiques, stratégies et renforcement des capacités : scénario actuel et initiatives}

\section{Résumé}

Contexte: L'Afghanistan est confronté à un lourd fardeau de malnutrition chez les femmes et les enfants et à une charge croissante de maladies non transmissibles.

Objectifs : Un examen narratif a été mené afin de cartographier les politiques de nutrition actuelles et les initiatives de développement des capacités afin d'évaluer la politique et l'environnement institutionnel et d'identifier les lacunes et les opportunités.

Méthodes : Une recherche complète et large a été menée, y compris sur des bases de données, des sites web et des documents de politique et de programme.

Résultats: La politique est axée sur les efforts multisectoriels pour relever les défis en matière de nutrition ; toutefois, la mise en œuvre d'interventions spécifiques et sensibles à la nutrition n'est pas réalisée de manière uniforme au niveau communautaire en raison de la persistance des situations de conflit et de l'inaccessibilité géographique, du manque de disponibilité de ressources humaines formées et de la faiblesse des institutions. Il existe peu de bases factuelles sur l'efficacité de programmes de nutrition en Afghanistan. Des dispositions politiques limitées sont disponibles pour traiter les problèmes de nutrition dus à la charge croissante des maladies non transmissibles, à l'urbanisation et à l'évolution des habitudes alimentaires. La pénurie de professionnels de la nutrition compétents est un problème critique. Le manque de capacités institutionnelles, de normes éducatives et de mécanismes d'accréditation constitue un défi majeur. Les programmes de formation actuels sont fragmentés et ne répondent pas aux exigences du personnel professionnel de la nutrition.

Conclusion: Les résultats de l'étude mettent en évidence le fait que des politiques et des stratégies bien structurées axées sur la nutrition chez la mère et l'enfant fournissent un environnement politique favorable à l'intensification des interventions nutritionnelles. Les bases factuelles sur la mise en œuvre des programmes sont nécessaires pour aider à formuler des recommandations politiques. Le manque de mécanisme institutionnel pour l'éducation professionnelle en matière de nutrition souligne le grand besoin d'action en faveur de la nutrition et l'éducation en santé publique en Afghanistan.

$$
\text { التغذية في ججال الصحة العامة في أفغانستان: السياسات والاستر اتيجيات وبناء القدرات: السيناريو الحالي والمبادرات }
$$

$$
\begin{aligned}
& \text { الخلفية: تو اجه أفغانستان عبئًا ثقيًا بسبب سوء التغذية بين النساء و الأطفال، وعبئًا متزايًًا بسبب الأمر اض غير السارية. } \\
& \text { الأهداف: هدفت هذه الدر اسة إلى إجراء استعر اض سردي لتوصيف سياسات التغذية الحالية ومبادرات تنمية القدرات، لتقييم السياسات و البيئة }
\end{aligned}
$$

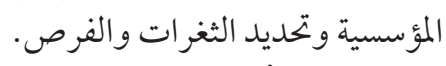

$$
\begin{aligned}
& \text { طرق البحث: أجري بحث شامل وو اسع النطاق يشمل قو اعد البيانات والمواقع الإلكترونية ووثائق السياسات و البرامج. }
\end{aligned}
$$

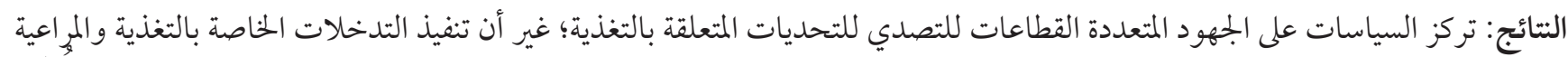

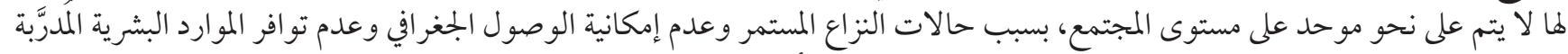

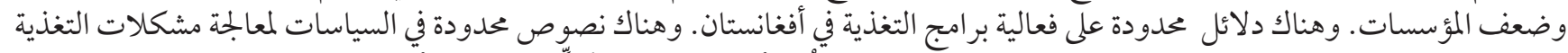

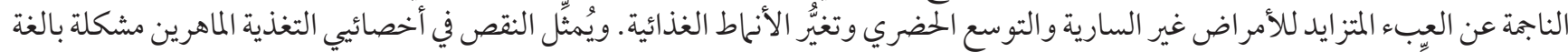

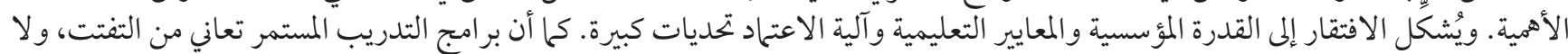
تلبي متطلبات القوى العاملة لأخصائيي التغذية. الأفئة

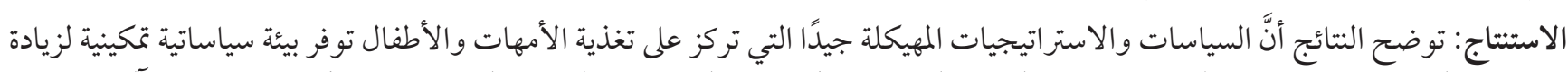

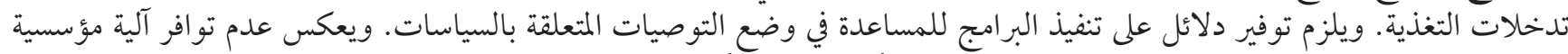

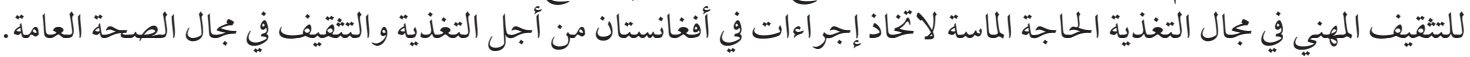

\section{References}

1. Victora CG, Adair L, Fall C, Hallal PC, Martorell R, Richter L, et al. Maternal and child undernutrition: consequences for adult health and human capital. Lancet. 371(9609):340-57. doi:10.1016/So140-6736(07)61692-4

2. Hoddinott J, Alderman H, Behrman JR, Haddad L, Horton S. The economic rationale for investing in stunting reduction. Matern Child Nutr. 2013 Sep;9(Suppl. 2):69-82. doi:10.1111/mcn.12080 
3. Grosse SD, Roy K. Long-term economic effect of early childhood nutrition. Lancet. 371(9610):365-6. doi:10.1016/So1406736(08)60180-4

4. Progress for children beyond averages: learning from the MDGs. New York: United Nations Children's Fund; 2015 (https://www. unicef.org/publications/files/Progress_for_Children_No._11_22June15.pdf, accessed 17 April 2017).

5. Monitoring the situation of children and women 2017. New York: United Nations Children's Fund; 2017 (https://data.unicef.org/ topic/nutrition/malnutrition/\#, accessed 17 April 2017)

6. Black RE, Alderman H, Bhutta ZA, Gillespie S, Haddad L, Horton S, et al. Maternal and child nutrition: building momentum for impact. Lancet. 2013;382(9890):372-5. doi:10.1016/S0140-6736(13)60988-5

7. Black RE, Allen LH, Bhutta ZA, Caulfield LE, de Onis M, Ezzati M, et al. Maternal and child undernutrition: global and regional exposures and health consequences. Lancet. 2008;371(9608):243-60. doi:10.1016/S0140-6736(07)61690-0. PMID: 18207566.

8. Global nutrition targets 2025: policy brief series. Geneva: World Health Organization; 2014 (WHO/NMH/NHD/14.2; http://apps. who.int/iris/bitstream/10665/149018/1/WHO_NMH_NHD_14.2_eng.pdf?ua=1, accessed 27 February 2021).

9. Global nutrition report: actions and accountability to accelerate the world's progress on nutrition. Washington, DC: International Food Policy Research Institute; 2015 (http://ebrary.ifpri.org/utils/getfile/collection/p15738coll2/id/128484/filename/128695.pdf, accessed 27 February 2021).

10. Horton R, Lo S. Nutrition: a quintessential sustainable development goal. Lancet. 2013;382(9890):371-2. doi:10.1016/So1406736(13)61100-9

11. Walters D, Kakietek J, Eberwein JD, Shekar M. An investment framework for nutrition: reaching the global targets for stunting, anemia, breastfeeding, and wasting. Washington, DC: World Bank 2017 (http://documents1.worldbank.org/curated/ en/244081491391841079/pdf/114022-BRI-Anemia-rev-v5-WEB-PUBLIC.pdf, accessed 27 February 2021).

12. Afghanistan health situation reports. Cairo: World Health Organization Regional Office for the Eastern Mediterranean; 2002 (https://www.who.int/hac/crises/afg/sitreps/en/, accessed 6 August 2020).

13. Richards T. Afghanistan struggles to build post-conflict health care. BMJ. 2003 Apr 19;326(7394):837. doi:10.1136/bmj.326.7394.837/a

14. Acerra JR, Iskyan K, Qureshi ZA, Sharma RK. Rebuilding the health care system in Afghanistan: an overview of primary care and emergency services. Int J Emerg Med. 2009 Jun 5;2(2):77-82. doi:10.1007/s12245-009-0106-y

15. Afghanistan service provision assessment 2018-19. Kabul: Afghanistan: Ministry of Public Health, Afghanistan, and ICF; 2019.

16. Frost A, Wilkinson M, Boyle P, Patel P, Sullivan R. An assessment of the barriers to accessing the Basic Package of Health Services (BPHS) in Afghanistan: was the BPHS a success? Global Health. 2016;12(1):71. doi:10.1186/s12992-016-0212-6

17. Global Hunger Index 2019. Dublin: Concern Worldwide and Welthungerhilfe; 2020 (https://www.globalhungerindex.org/results. html, accessed 6 August 2020).

18. Hunger and nutrition commitment index global: key data for Afghanistan. Brighton: Institute of Development Studies and Irish Aid; 2019. (http://www.hancindex.org/countries/afghanistan/, accessed 19 August 2020.

19. Akseer N, Bhatti Z, Mashal T, Soofi S, Moineddin R, Black RE, et al. Geospatial inequalities and determinants of nutritional status among women and children in Afghanistan: an observational study. Lancet Glob Health. 2018;6(4):e447-e59. doi:10.1016/ S2214-109X(18)30025-1

20. Sachs JD. From millennium development goals to sustainable development goals. Lancet. 2012;379(9832):2206-11. doi:10.1016/ So140-6736(12)60685-0

21. Fanzo JC, Graziose MM, Kraemer K, Gillespie S, Johnston JL, de Pee S, et al. Educating and training a workforce for nutrition in a post-2015 world. Adv Nutr. 2015;6(6):639-47. doi:10.3945/an.115.010041

22. Kim C, Mansoor GF, Paya PM, Ludin MH, Ahrar MJ, Mashal MO, et al. Multisector nutrition gains amidst evidence scarcity: scoping review of policies, data and interventions to reduce child stunting in Afghanistan. Health Res Policy Syst. 2020 Jun 11;18(1):65. doi:10.1186/s12961-020-00569-x

23. National nutrition and food security country paper: Afghanistan. International Conference on Nutrition - 20 Years Later (ICN+20). Rome: World Health Organization and Food and Agriculture Organization; 2014.

24. National nutrition survey Afghanistan. Kabul: UNICEF Afghanistan, and Ministry of Public Health, Public Nutrition Department; 2013.

25. National Nutrition Survey Afghanistan. Kabul: UNICEF Afghanistan, and Ministry of Public Health, Public Nutrition Department; 2004

26. Higgins-Steele A, Mustaphi P, Varkey S, Ludin H, Safi N, Bhutta ZA. Stop stunting: situation and way forward to improve maternal, child and adolescent nutrition in Afghanistan. Matern Child Nutr. 2016 May;12(Suppl. 1):237-41. doi:10.1111/mcn.12288

27. Afghanistan Demographic and Health Survey 2015. Kabul: Central Statistics Organization, Ministry of Public Health and ICF; 2017.

28. Afghanistan National Health Policy (2015-2020). Kabul: Ministry of Public Health; 2015.

29. Kim C, Mansoor GF, Paya PM, Ludin MH, Ahrar MJ, Mashal MO, et al. Review of policies, data, and interventions to improve maternal nutrition in Afghanistan. Matern Child Nutr. 2020 Oct;16(4):e13003. doi:10.1111/mcn.13003 
30. Afghanistan food security and nutrition agenda (AFSANA): A policy and strategic framework. Kabul: Government of the Islamic Republic of Afghanistan 2012 (http://extwprlegsi.fao.org/docs/pdf/afg152445.pdf, accessed 27 February 2021).

31. National public nutrition strategy (2015-2020). Kabul: Ministry of Public Health, Islamic Republic of Afghanistan, 2015.

32. Standard operational procedure guideline for nutrition in BPHS\&EPHS. Kabul: Ministry of Public Health, Islamic Republic of Afghanistan, 2015.

33. Howard N, Woodward A, Patel D, Shafi A, Oddy L, Veen At, et al. Perspectives on reproductive healthcare delivered through a basic package of health services in Afghanistan: a qualitative study. BMC Health Serv Res. 2014;14:359. doi:10.1186/1472-6963-14-359

34. Nasrat Q. Assessment of nutrition interventions in BPHS AND EPHS health facilities in Afghanistan. Kabul: Public Nutrition Department, Ministry of Public Health; 2014 (http://www.orcd.org/Resources/Final\%20Report\%20Nutrition\%20Assessment\%20 07\%2008.pdf, accessed 26 February 2021).

35. Yngve A, Tseng M, Haapala I, Hodge A. A robust and knowledgeable workforce is essential for public health nutrition policy implementation. Public Health Nutr. 2012;15(11):1979-80. doi:10.1017/S1368980012004570.

36. Country cooperation strategy for WHO and Afghanistan 2009-2013 Cairo: World Health Organization Regional Office for the Eastern Mediterranean; 2010 (WHO-EM/ARD/043/E; http://applications.emro.who.int/docs/CCS_Afghanistan_2010_EN_14480. pdf, accessed 27 February 2021).

37. Singh P, Rai R, Alagarajan M. Addressing maternal and child health in post-conflict Afghanistan: the way forward. East Mediterr Health J. 2013 Sep;19(9):826-31. PMID: 24313047

38. Jackson A, Ashworth A. Capacity-building in the management of moderate acute malnutrition. Food Nutr Bull. 2015 Mar;36(1 Suppl):S47-52. doi:10.1177/15648265150361S108

39. Khandelwal S, Paul T, Haddad L, Bhalla S, Gillespie S, Laxminarayan R. Postgraduate education in nutrition in south Asia: a huge mismatch between investments and needs. BMC Med Educ. 2014;14:3. doi:10.1186/1472-6920-14-3

40. Gillespie S, Menon P, Kennedy AL. Scaling up impact on nutrition: what will it take? Adv Nutr. 2015 Jul 15;6(4):440-51. doi:10.3945/an.115.008276

41. Newbrander W, Ickx P, Feroz F, Stanekzai H. Afghanistan's basic package of health services: its development and effects on rebuilding the health system. Glob Public Health. 2014;9(Suppl. 1):S6-S28. doi:10.1080/17441692.2014.916735

42. Gillespie S, Haddad L, Mannar V, Menon P, Nisbett N. The politics of reducing malnutrition: building commitment and accelerating progress. Lancet.382(9891):552-69. doi:10.1016/So140-6736(13)60842-9

43. Sunguya BF, Poudel KC, Mlunde LB, Urassa DP, Yasuoka J, Jimba M. Nutrition training improves health workers' nutrition knowledge and competence to manage child undernutrition: a systematic review. Front Public Health. 2013 Sep 24;1:37. doi:10.3389/fpubh.2013.00037

44. Geissler C, Amuna P, Kattelmann KK, Zotor FB, Donovan SM. The eNutrition Academy: supporting a new generation of nutritional scientists around the world. Adv Nutr. 2016;7(1):190-8. doi:10.3945/an.115.010728

45. Khandelwal S, Dayal R, Jha M, Zodpey S, Reddy KS. Mapping of nutrition teaching and training initiatives in India: the need for Public Health Nutrition. Public Health Nutr. 2012;15(11):2020-5. doi:10.1017/S1368980011003016

46. Delisle H, Shrimpton R, Blaney S, Du Plessis L, Atwood S, Sanders D, et al. Capacity-building for a strong public health nutrition workforce in low-resource countries. Bull World Health Organ. 2017 May 1;95(5):385-8. doi:10.2471/BLT.16.174912. Epub 2017 Apr 5. PMID: 28479641

47. Shrimpton R, du Plessis LM, Delisle H, Blaney S, Atwood SJ, Sanders D, et al. Public health nutrition capacity: assuring the quality of workforce preparation for scaling up nutrition programmes. Public Health Nutr. 2016;19(11):2090-100. doi:10.1017/ S136898001500378X

48. Geissler C. Capacity building in public health nutrition. Proc Nutr Soc. 2015 Nov;74(4):430-6. doi:10.1017/So029665114001736 